\title{
Patterns of Cancer in Kurdistan - Results of Eight Years Cancer Registration in Sulaymaniyah Province-Kurdistan-Iraq
}

\author{
Najmaddin Khoshnaw ${ }^{1,4 *}$, Hazha A Mohammed ${ }^{2}$, Dana A Abdullah ${ }^{3}$
}

\begin{abstract}
Background: Cancer has become a major health problem associated with high mortality worldwide, especially in developing countries. The aim of our study was to evaluate the incidence rates of different types of cancer in Sulaymaniyah from January-2006 to January-2014. The data were compared with those reported for other middle east countries. Materials and Methods: This retrospective study depended on data collected from Hiwa hospital cancer registry unit, death records and histopathology reports in all Sulaymaniyah teaching hospitals, using international classification of diseases. Results: A total of $\mathbf{8 , 0 3 1}$ cases were registered during the eight year period, the annual incidence rate in all age groups rose from 38 to 61.7 cases/100,000 population/year, with averages over 50 in males and 50.7 in females. The male to female ratio in all age groups were 0.98 , while in the pediatric age group it was 1.33 . The hematological malignancies in all age groups accounted for $20 \%$ but in the pediatric group around half of all cancer cases. Pediatric cancers were occluding $7 \%$ of total cancers with rates of 10.3 in boys and 8.7 in girls. The commonest malignancies by primary site were leukemia, lymphoma, brain, kidney and bone. In males in all age groups they were lung, leukaemia, lymphoma, colorectal, prostate, bladder, brain, stomach, carcinoma of unknown primary (CUP) and skin, while in females they were breast, leukaemia, lymphoma, colorectal, ovary, lung, brain, CUP, and stomach. Most cancers were increased with increasing age except breast cancer where decrease was noted in older ages. High mortality rates were found with leukemia, lung, lymphoma, colorectal, breast and stomach cancers. Conclusions: We here found an increase in annual cancer incidence rates across the period of study, because of increase of cancer with age and higher rates of hematological malignancies. Our study is valuable for Kurdistan and Iraq because it provides more accurate data about the exact patterns of cancer and mortality in our region.
\end{abstract}

Keywords: Cancer - incidence - epidemiology - Hiwa hospital - Sulaymaniyah-Iraq

Asian Pac J Cancer Prev, 16 (18), 8525-8531

\section{Introduction}

Cancer is regarded as the major cause of death worldwide and also became a major health concern in Kurdistan. The incidence of cancer is increasing, yearly more than fifteen million new cases were diagnosed and nearly half of them died by cancer (Quinn et al., 2003; Salminen et al., 2005; Sener and Grey, 2005; Ferlay et al., 2007) Cancer is increasing with age (Ma and $\mathrm{Yu}, 2006$ ). Few years ago cancer was accounts for $1 / 10$ th deaths in developing countries (Parkin, 1999). Although cancer rates were increased in developing countries but still the rate is lower than that found in developed countries and The mortality rate by cancer will be doubled by year 2020 (Stewart, 2003). Cancers like breast, colon and uterus are increasing in developing countries, due to life style changes as the former types were more reported in western form of lifestyle (WHO, 2003; Plesnicar and Plesnicar, 2001).
It is proved that factors like social, behavioral, economy and lifestyle may interact and affects the frequency and type of cancer (Anzola, 2004; Denny, 2005).

Many causes of cancer have been described and it appeared to be multi factorial. Infectious agents blamed to be the cause in more than quarter of the cases in developing countries while only accounts for only $10 \%$ in developed countries (Facer and Playfair, 1989; Magrath et al., 1992; Fischbach et al., 1997; Rastogi et al., 2004). Environment has a role in certain types of cancer as oral cancer is more in those using betel nuts and tobacco chewing. (Denny, 2005) lung cancer in china due to indoor pollutions by radon and smoking (Stewart, 2003) and narghile (waterpipe) smoking in middle east countries (Monzer et al., 2008) Tobacco accounts for one third of the cancer deaths (Jones, 1999).

Cancer can be avoided, it is among the most preventable and treatable chronic diseases by change in lifestyle and

${ }^{1}$ Department of Hematology, Hiwa Hospital, ${ }^{2}$ Department of Medicine, School of Medicine, Faculty of Medical Sciences, University of Sulaimani, ${ }^{3}$ Department of Pathology and Forensic Pathology, School of Medicine, Faculty of Medical Sciences, University of Sulaimani, Sulaymaniyah, Kurdistan Region, ${ }^{4}$ Kurdistan Board for Medical Specialties, Trainee Affairs, Ministry of Higher Education and Scientific Research, Erbil, Kurdistan Region, Iraq ${ }^{\circledR}$ Equal contributors *For correspondence: najmaddin_salih@yahoo.com 
food, decreases the risk of cancer (Magrath and Litvak, 1993); www.wer-Uk.org) Early detection and treatment of certain predisposing factors with prevention and treatment of certain types of bacterial and viral infections have a role in decreasing cancer incidence and mortality in developed countries (Jones, 1999; Denny, 2005).

After Iraqi regime has been destroyed on 2003, a rapid change occurred in lifestyle of Kurdish people that affected the patterns and rates of cancer trends in Kurdistan. The effect of devastating three vicious wars in Iraq with the use of different chemical weapons of mass destruction may have the role in environmental pollution and increasing cancer incidence, especially high rates of hematological malignancies. Few published data are present giving some information about some of cancers in Kurdistan (Khoshnaw N, 2014; Majid R, 2012;

Table 1. The Annual Incidence Rates in Both Sexes and All Age Groups per 100,000 Populations per Year in Sulaymaniyah Province from January-2006 to January-2014

\begin{tabular}{lcccc}
\hline Years & $\begin{array}{c}\text { Total } \\
\text { Population }\end{array}$ & $\begin{array}{c}\text { Annual IR } \\
\text { in Male }\end{array}$ & $\begin{array}{c}\text { Annual IR } \\
\text { in Female }\end{array}$ & Annual IR* \\
\hline 2006 & $1,811,135$ & 37 & 40 & 38.5 \\
2007 & $1,867,347$ & 39 & 46 & 42.62 \\
2008 & $1,923,368$ & 45.2 & 48.58 & 48.89 \\
2009 & $1,981,067$ & 51.73 & 49,43 & 50.52 \\
2010 & $2,031,826$ & 49.42 & 49.7 & 50.59 \\
2011 & $2,092,780$ & 54.59 & 58.5 & 56.52 \\
2012 & $2,155,563$ & 58.67 & 62.46 & 60.58 \\
2013 & $2,218,000$ & 60.2 & 63.25 & 61.7 \\
\hline
\end{tabular}

*IR; incidence rate

Table 2. Cancer Incidence Rates per 100,000 Populations by Age Group among the Male Population in Sulaymaniyah-Kurdistan Region of Iraq, during 2006-2014.

\begin{tabular}{|c|c|c|c|c|c|c|c|}
\hline ICD 10 & Site & $(1-14)$ & $(15-24)$ & $\begin{array}{c}\text { Age groups } \\
(25-54)\end{array}$ & $(55-64)$ & $(65+)$ & All age groups \\
\hline C33-34 & Lung & l & l & 3.15 & 51.3 & 121 & 7.12 \\
\hline C91-95 & leukemias & 3.57 & 2.34 & 3.08 & 12.76 & 24.57 & 4.5 \\
\hline C81-88,C96 & Lymphomas & 1.96 & 1.88 & 3.45 & 9.01 & 19.6 & 4.32 \\
\hline C18-21 & Colorectal & I & 0.72 & 1.9 & 15.45 & 33.3 & 3.89 \\
\hline C61 & Prostate & l & I & 0.35 & 13.3 & 89.5 & 3.5 \\
\hline C67 & Bladder & / & 0.12 & 1.72 & 20.5 & 55.6 & 3.07 \\
\hline C70-72 & Brain & 1.95 & 0.93 & 2.59 & 11.8 & 7.09 & 2.7 \\
\hline C16 & Stomach & I & 0.13 & 1.8 & 18.27 & 46.33 & 2.6 \\
\hline C76 & CUP & 0.06 & I & 1.38 & 13 & 24.48 & 2.45 \\
\hline C43-44,C04 & Skin & 0.07 & 0.71 & 1.4 & 14.76 & 28 & 2.03 \\
\hline C45,C47 & MPN & 0.03 & 0.63 & 1.6 & 7.75 & 19.6 & 1.66 \\
\hline C64-66 & Kidney & 0.72 & I & 1.15 & 30.65 & 15 & 1.35 \\
\hline C32 & Larynx & I & I & 0.41 & 10.7 & 23.7 & 1.32 \\
\hline C47-49 & soft tissue Sarc. & 0.34 & 0.7 & 1.16 & 3.6 & 8.8 & 1.13 \\
\hline $\mathrm{C} 25$ & Pancrease & I & I & 0.78 & 5.7 & 13.7 & 1.11 \\
\hline $\mathrm{C} 00-14$ & Head \& neck & 0.34 & 0.64 & 7.9 & 6.9 & 7.58 & 1.07 \\
\hline C15 & Eosophagous & 1 & 1 & 0.45 & 5.07 & 18.77 & 0.96 \\
\hline C90 & MM & l & l & 6.63 & 6 & 8.9 & 0.74 \\
\hline $\mathrm{C} 22$ & Liver & 0.2 & / & 0.9 & 4.47 & 8.4 & 0.71 \\
\hline C62 & testis & 0.37 & 0.44 & 0.96 & 1.8 & 0.8 & 0.7 \\
\hline C40-41 & Bone & 0.47 & 0.96 & 0.41 & 1.19 & 1.7 & 0.68 \\
\hline C23-24 & GB \& BT & I & I & 0.44 & 3.6 & 6.8 & 0.52 \\
\hline C73 & thyroid & l & 0.32 & 0.58 & 1.9 & 2 & 0.42 \\
\hline \multirow[t]{3}{*}{$\mathrm{C} 46$} & MDS & 0.1 & 0.06 & 0.34 & 0.6 & 1.6 & 0.26 \\
\hline & Other sites & 0.1 & 0.7 & 1.4 & 6.6 & 10.9 & 1.3 \\
\hline & & 10.28 & 11.28 & 45.93 & 276.68 & 597.72 & 50.11 \\
\hline
\end{tabular}

Zangana A, 2012; Othman et al., 2011) but no one giving information in detail. Our study is presenting new accurate data on the patterns of caners in Kurdistan.

\section{Materials and Methods}

This study is a hospital based, retrospective cohort study, depended on the data collection from Hiwa hospital data registry unit, pathology unit in Shorsh hospital and all surgical, medical, pediatric, emergency teaching hospitals of the Sulaymaniyah governorate. A total of 11,872 cases have been registered in Hiwa hospital during January 2006 to January 2014, out of these 3,841 cases are those patients from other governorates and refugees, which were not included in this study. The remaining 8031 cases are those from the sulaymaniyah governorate. They were sorted depending on the Iraqi ID cards.

Data put in an excel sheet all duplicated names are removed; data sorted and classified using international classification of diseases (ICD10). Data include name, age, sex, address, occupation, date of diagnosis, type of cancer, primary site of involvement, and organ system involvement. Basal cell carcinoma was our exclusion criteria. Sulaymaniyah located in the north east of Kurdistan region of Iraq, most beautiful city, around 700 feet above sea level, covering a population of about 2 million peoples ranging from 1.8- 2.2 million from the year 2006-2014 respectively.

The sulaymaniyah peoples like other Middle East countries are young age population, in which only $3.2 \%$ are above 65 years of age(https://www.cia.gov/library/ 
Patterns of Cancer in Kurdistan; an Eight Years Cancer Registry in Sulaymaniyah Province-Kurdistan-Iraq

publications/the-world-factbook/geos/iz.html, 2015). Hiwa hospital is the only referral center for cancer registry for the whole sulaymaniyah governorate

SPSS 19 version used for statistical evaluation, the level of P-value $<0.05$ considered as significant value.

\section{Results}

A total of 8,031 cases have been recorded during the eight year period starting from January 2006 to January 2014 , the annual incidence rate in all age groups raised from 38 to 61.7 cases/ 100,000 population/ year in 2006, 2013 , respectively, which indicate nearly $61 \%$ increase in the cancer record in Sulaymaniyah during 8 years period (table 1). The haematological malignancies in all age groups account for $22.9 \%$ and $17.6 \%$ in male and female respectively, while in paediatric age (1-14 years) accounts for half of the cases $(50.8 \%)$. (table $2 \& 3)$.
The cancer incidence rates (IR) is increasing with age as we found age specified incidence rate of 597.7 cases in male and 363 cases in females /100,000/population/ year those aged 65 years and more while lowest incidence found in paediatric age group (figure 1). Cancer IR in all age groups of sulaymaniyah population during whole eight years period is $50.1 \mathrm{in}$ male and 50.7 in females/ 100,000 population/ year. Male to female ratio in all age groups and all cancers were 0.98 , While in paediatric ages is 1.33 (male $57.3 \%$, female $42.7 \%$ ).

The malignancies in paediatric age group were occluding only $7.1 \%$ (number 573) of all cancer cases registered despite the young population of Kurdistan (36\% below 15 years) The AIR in paediatric ages were 10.3 in boys and 8.7 in girls/100,000 population/ year. The commonest malignancies /AIR were leukaemia 3.57, lymphoma 1.96 , brain 1.95 , kidney 0.72 and bone 0.42 cases / 100,000 / year in boys and Leukaemia 2.97, brain

Table 3. Cancer Incidence Rates per 100,000 Populations by Age Group among the Females in SulaymaniyahKurdistan Region of Iraq, During January 2006-January 2014

\begin{tabular}{|c|c|c|c|c|c|c|c|}
\hline ICD10 & Site & $(1-14)$ & $(15-24)$ & $\begin{array}{l}\text { Age groups } \\
(25-54)\end{array}$ & $(55-64)$ & $(65+)$ & all age groups \\
\hline $\mathrm{C} 50$ & Breast & 0.03 & 0.76 & 31.1 & 82.8 & 68 & 17.1 \\
\hline C91-95 & Leukemia & 2.97 & 1.97 & 2.95 & 11.9 & 36.8 & 3.72 \\
\hline C81-88,C96 & lymphoma & 1.11 & 1.97 & 3.1 & 10.1 & 21 & 2.96 \\
\hline $\mathrm{C} 18-21$ & Colo-rectal & 0.03 & 0.57 & 3.79 & 14.8 & 24.3 & 2.91 \\
\hline $\mathrm{C} 52$ & Ovary & 0.13 & 0.24 & 2.96 & 11.6 & 11.95 & 2.21 \\
\hline C33-34 & Lung & 1 & 0.13 & 1.5 & 11 & 28.4 & 1.94 \\
\hline C70-72 & Brain & 1.75 & 0.76 & 1.57 & 7.6 & 7 & 1.91 \\
\hline C76 & CUP & 0.13 & 0.38 & 1.3 & 12.2 & 23.9 & 1.83 \\
\hline $\mathrm{C} 16$ & Stomach & 1 & 1.52 & 1.9 & 9.8 & 20.6 & 1.8 \\
\hline C43-44,C04 & Skin & 0.2 & 0.13 & 1.12 & 8.6 & 15.7 & 1.37 \\
\hline $\mathrm{C} 53$ & Endo/UT & I & 0.12 & 1.87 & 9.9 & 6.6 & 1.34 \\
\hline $\mathrm{C} 45, \mathrm{C} 47$ & MPN & 0.03 & 0.19 & 0.4 & 10.75 & 12.7 & 1.3 \\
\hline C47-49 & Soft tissue & 0.33 & 0.63 & 0.34 & 3.6 & 5.35 & 1.08 \\
\hline C73 & Thyroid & 0.07 & 0.5 & 1.6 & 4.06 & 4.5 & 1.04 \\
\hline C64-66 & kidney & 0.5 & 0.12 & 0.86 & 2.6 & 2.12 & 0.85 \\
\hline $\mathrm{C} 15$ & Esophagus & I & 1 & 0.42 & 5.23 & 13.18 & 0.8 \\
\hline $\mathrm{C} 25$ & pancreas & 1 & 0.1 & 0.48 & 4.8 & 10.8 & 0.78 \\
\hline $\mathrm{C} 00-14$ & Head and Neck & 0.24 & 0.25 & 0.69 & 3.8 & 6.6 & 0.74 \\
\hline C67 & Bladder & 1 & 1 & 0.3 & 4.8 & 12.36 & 0.66 \\
\hline C90 & MM & / & / & 0.3 & 6.3 & 7.8 & 0.63 \\
\hline C23-24 & GB and BT & / & 1 & 0.55 & 4 & 5.6 & 0.57 \\
\hline $\mathrm{C} 54$ & Cervix & 1 & 0.06 & 0.58 & 4.7 & 1.23 & 0.45 \\
\hline C40-41 & Bone & 0.46 & 0.7 & 0.3 & 0.87 & 2 & 0.38 \\
\hline $\mathrm{C} 22$ & Liver & 0.07 & / & 0.34 & 1.2 & 3.6 & 0.34 \\
\hline \multirow[t]{2}{*}{ C46 } & MDS & 0.06 & 0.25 & 0.13 & 1.75 & 3.7 & 0.31 \\
\hline & GIST & 1 & 0.1 & 0.24 & 0.89 & 2.88 & 0.24 \\
\hline \multirow[t]{3}{*}{$\mathrm{C} 32$} & Larynx & 1 & 1 & 0.55 & 0.9 & 2.9 & 0.23 \\
\hline & Others & 0.6 & 0.9 & 90 & 6.2 & 1.7 & 1.24 \\
\hline & & 8.71 & 12.35 & 151.24 & 255.86 & 363.27 & 50.73 \\
\hline
\end{tabular}

Table 4. Cancer Incidence Rates per 100,000 Populations in Pediatric Age Group (1-14 years) in Both Boys and Girls in Sulaymaniyah-Kurdistan Region of Iraq, from January 2006-January 2014

\begin{tabular}{llllll}
\hline & Boys & Age 1-14 & & Girls \\
\hline ICD10 & primary site & $/ 100,000$ & ICD10 & primary site & $/ 100,000$ \\
C91-95 & leukemia & 3.57 & C91-95 & leukemia & 2.97 \\
C81-88,C96 & Lymphoma & 1.96 & C70-72 & brain & 1.75 \\
C70-72 & Brain & 1.95 & C81-88,C96 & lymphoma & 1.11 \\
C64-66 & Kidney & 0.72 & C64-66 & kidney & 0.5 \\
C40-41 & Bone & 0.47 & C40-41 & bone & 0.46 \\
\hline
\end{tabular}


1.75 , lymphoma 1.1 , kidney 0.5 , and bone 0.46 cases $/ 100,000$ population / year in girls (table.4).

The ten most common cancers/AIR in all age groups in males were lung 7.12, leukaemia 4.5, lymphoma 4.32, colorectal 3.89 , prostate 3.5 , bladder 3.1, brain 2.7,

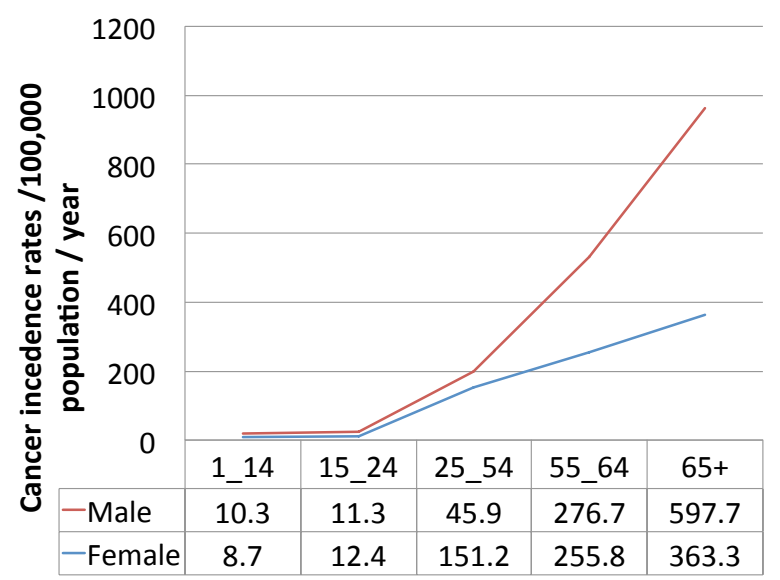

Figure 1. Annual Incidence Rates by Age Groups Increased with Increasing Age

Table 5. Commonest Cancer Related Mortality in Both Sexes in Sulaymaniyah Population from January 2006 to January 2014 and Compare to that found in worldwide 2012

\begin{tabular}{lccc}
\hline $\begin{array}{l}\text { Sulaymaniyah/ } \\
\text { Kurdistan 2006-2013 }\end{array}$ & $\begin{array}{c}\text { Globacan 2012: Estimated cancer } \\
\text { mortality worldwide in 2012. }\end{array}$ \\
\hline Primary site & Percentage & Primary site & Percentage \\
leukemia & $23 \%$ & Breast & $19.20 \%$ \\
lung & $11.30 \%$ & Prostate & $11.90 \%$ \\
lymphoma & $10.90 \%$ & Colorectal & $10.90 \%$ \\
colorectal & $8.60 \%$ & Lung & $5.80 \%$ \\
breast & $8 \%$ & Cervix & $4.80 \%$ \\
stomach & $4.40 \%$ & Stomach & $4.70 \%$ \\
CUP & $4 \%$ & Uterus & $3.70 \%$ \\
brain & $3.80 \%$ & Bladder & $4.10 \%$ \\
pancreas & $3.30 \%$ & Esophagus & $1.40 \%$ \\
ovary & $2.20 \%$ & Ovary & $1.80 \%$ \\
MM & $2.20 \%$ & & \\
\hline
\end{tabular}

stomach(2.6), carcinoma of unknown primary (CUP) 2.45 and skin 2 cases $/ 100,000$ population (table. 2 ), while in females were breast 17.1, leukaemia 3.7, lymphoma 2.96, colorectal 2.91 , ovary 2.2 , lung 1.94 , brain 1.9 , CUP 1.83 , and stomach 1.8 cases $/ 100,000$ population / year (table.3).. There was an estimated mortality of 5.6 cases/ $100,000 /$ year of sulaymaniyah population. During the eight year period we found that $1 / 8(12.5 \%)$ of our newly diagnosed cases were died by cancer. The commonest cause of mortality was Leukemia (23\%), lung (11.3\%), lymphoma $(10.9 \%)$, colorectal $(8.6 \%)$, breast $(8 \%)$ and stomach $(4.4 \%)$ cancers. (table.5)

\section{Discussion}

Cancer became a major cause of death with an increasing in IR worldwide especially in developing countries. Despite a rapid increase in cancer in developing countries and Kurdistan but still not reaching to the rates found in the western countries (Ferlay J, 2010). In our province we found higher rates of hematological malignancies in compare to other populations as we compared to surrounding countries in (middle east cancer consortium, 2005; Siegel R, 2014) The cause is not explained till now but many factors have been mentioned as Iraq and specifically Kurdistan exposed to repeated vicious wars, starting from Iraq-Iran war, first and second gulf war until the Iraqi operation freedom; Kurdistan was bombarded by thousands of weapons of mass destruction. During last 35 years of Saddam regime, many cities and villages were under the attack by chemical weapons as that happened in Halabja, poverty, inadequate food, vaccines and medicine supply, use of uranium in the south part of Iraq, and oil wheel fire in gulf war in south of Basra that led to air pollution was blamed to have effect of an increased cancer rate specifically hematological malignancies in Iraq (table 1-6).

Cancer registry in Kurdistan were under estimated before 2004 but improved because of many factors like improvement in health education, lifestyle change, early detection of cancer cases may have a role in

Table 6. Incidence Rates for all Sites of Cancers in both Sexes per 100,000 of Sulaymaniyah/Kurdistan Population and top ten Major Cancers in Both Sexes and All Age Groups Compared to the Surrounding Countries and USA SEER Data

\begin{tabular}{|c|c|c|c|c|c|c|c|}
\hline Primary site & $\begin{array}{l}\text { Sulaymaniyah* } \\
\text { /Kurdistan } \\
\text { (2006-2013) }\end{array}$ & $\begin{array}{l}\text { Qatar* } \\
2006\end{array}$ & $\begin{array}{c}\text { Jordan }^{\&} \\
(1996-2001)\end{array}$ & $\begin{array}{c}\text { Egypt }^{\&} \\
(1999-2001)\end{array}$ & $\begin{array}{c}\text { Israel }^{\&} \text { (Arabs) } \\
(1996-2001)\end{array}$ & $\begin{array}{c}\text { Cyprus }^{\&} \\
(1998-2001)\end{array}$ & $\begin{array}{c}\text { USA \& SEER } \\
\text { 1999-2001 }\end{array}$ \\
\hline Breast & 17.1 & 30 & 18.7 & 25 & 19.2 & 30.2 & 51 \\
\hline Lung & 4.5 & 4.8 & 9.9 & 7.7 & 20.4 & 13.4 & 39 \\
\hline Leukemia & 4.1 & 4.5 & 6.3 & 6 & 6.4 & 6.9 & 8.8 \\
\hline Female genital system & 4 & 9 & 6.6 & 6.4 & 8.1 & 10.6 & 19.6 \\
\hline Lymphoma & 3.6 & 6.8 & 8.9 & 16.3 & 12.9 & 10.6 & 15.3 \\
\hline Prostate & 3.5 & 3 & 5.6 & 3.6 & 8.4 & 16.4 & 52.9 \\
\hline Colorectal & 3.4 & 3 & 5.6 & 3.6 & 8.4 & 16.4 & 32 \\
\hline Brain & 2.3 & 1.7 & 3.7 & 3.2 & 3.6 & 4.1 & 12 \\
\hline Bladder & 2.2 & 1.4 & 7.6 & 16.6 & 8.6 & 11.2 & 4.9 \\
\hline Stomach & 2.2 & 2.25 & 4.8 & 2.9 & 4.6 & 4.9 & 5.3 \\
\hline Connective tissue & 1.6 & 3.3 & 1.1 & 2.8 & 0.8 & 1.4 & 0.8 \\
\hline Total & 50.4 & 63 & 113 & 143 & 149 & 164 & 318 \\
\hline
\end{tabular}

*Annual incidence rate, ${ }^{\&}$ Age standardized incidence rate 
increased cancer rates in compare to previous decade. High proportional rate of hematological malignancies in compare to others solid malignancies were unclear may be related to the above mentioned factors (Othman et al., 2011). Leukemias was the second malignancy after lung cancer in males and in females after breast cancer, and in both sexes account for the third most common cancer, the annual incidence rates in both sexes were 4.1/ 100,000 near to that found in Qatar 4.5 (Abdulbari B , 2007) higher rates found in other countries Jordan, Egypt, Israel Arab, Cyprus and USA were 6.3, 6, 6.4, 6.9 and 8.8 respectively (table 6).

Despite lymphomas and leukemias as part of hematological malignancies account for more than $20 \%$ but still we found lower annual incidence rates of lymphoma and leukemias in compare to other surrounding countries. The female genital malignancies were lower to that found in surrounding countries (table 6) this indicate that some cancers like cervical cancer and AIDS related malignancies are very rare in our community that is why we recorded high proportional rate of hematological malignancies.

The cancer IR in all age groups in Kurdistan for the year 2013 is 61.7 new cases /100,000 population which is near to that found in Qatar 63 (Abdulbari B, 2007) lower than that found in Jordan 113, Egypt 143, Cyprus 164, and UK 597 and USA SEER 318 cases in (Middle East Cancer Consortium, 2005)

In Kurdish population the breast, lung, leukaemia, lymphoma, colorectal, prostate and ovary account for $52 \%$ of all cancers in both sexes. But in United Kingdom; Breast, lung, prostate and bowel cancers together account for over half of all new cancers each year in both sexes (Ahmed AS, 2015). In United state, prostate cancer in male and breast cancer in female to be followed by cancer of lung and bronchus, to account for $41 \%$ of all cancer in male and $42 \%$ of all cancers in female (Siegel R, 2014)

The AINR of breast cancer in our region is 17.1/100,000 population / year which is near to that found in Jordan 18.7 and Israel Arabs 19.2, while higher rates recorded in Egypt 25, Cyprus 30 and USA is 51 (Middle East Cancer Consortium, 2005) while greater to that recorded in Oman is 13 (Executive Board of the Health Ministers' Council, 2002). Breast cancer is a very good parameter to compare our country to the surrounding countries which appear to some degree gave similar rates of cancer incidence, because nearly all cases of breast cancer have being recorded in our cancer registry unit( table 6.)

The commonest age group at presentation of breast cancer in our study is middle ages (55-64) years females same as reported in Qatar (55-64) while in Korea (45-54) (Shin HR, 2002). The age specified incidence rate is 82 cases $/ 100,000$, but decreased in older ages $>65$ years to $68 / 100,000$, Breast cancer in women is the most common cancer in Kurdistan and, Kuwait, Egyptian (Kahan et al., 1997). Many factors have effect on the breast cancer as diet, body mass index, physical activity, reproductive pattern and multi-parity.

In our study we found high rates of lung cancer and larynx in males (7.12 and 1.32 new cases $/ 100,000 /$ year). It was the first cancer in males and sixth cancer in female and second most common cancer in both sexes. We found nearly comparable AIR to that of Qatar 4.8 (Abdulbari B, 2007), but higher rates found in other countries Jordan, Egypt, Israel Arabs, Cyprus and USA which were 9.9, $7.7,20.4,13.4$, and 39 respectively. Majority of our cases were smokers as most of lung cancers worldwide are caused by tobacco smoking (Doll et al., 2005); International Agency for Research on Cancer, 2004; Boyle P, 2003).

Colorectal cancer trends increased in the second four years (2010-2013) in compare to the first four years and it accounts for fourth most common cancers in both sexes separately. It was reported that colorectal cancer associated with highly saturated diets and smoking for that early detection and screening for colorectal cancer has been shown to be effective (Boyle P, 2003; Faivre et al., 2004). We found slightly higher rates of colorectal cancer in Sulaymaniyah peoples 3.4 in compare to Qatar 3, near to the results of Egypt 3.6, while higher rates found in Israel Arabs 8.4, Cyprus 16.4, and USA 32.

A cording to the American cancer society in developed countries the three most common cancers in males are lung, stomach and liver wile in Kurdistan are lung, leukemia, and lymphoma, colorectal, prostate. in women the commonest cancer are breast, cervix, uterus and stomach while in Kurdistan, are breast, leukaemia, lymphoma, colorectal and ovary but in Qatar breast, and female genital tract are first two common cancers (Abdulbari B, 2007).

Prostate cancer is the fifth cancer in sulaymaniyah population with the AIR in males in all age group were $3.5 / 100,000$, it was increased with increasing age reaching to 89 cases $/ 100,000$ in those more than 65 years. Our results were more than in Qatar 3 (Abdulbari B, 2007), similar to Egypt 3.6, higher rate found in Jordan 5.6, and Cyprus 16.4 and 53 in USA (Middle East Cancer Consortium, 2005).

Brain cancer account for the third cancer in pediatric age groups, after leukemia and lymphoma, the AIR in all age groups in male 2.7, while in female is 1.9 , but in both sexes were 2.3 which indicate rates greater than in Qatar 1.7, lesser than found in Jordan, Egypt, Israel Arabs, Cyprus, and USA were 3.7, 3.2, 3.6, 4.2 and 12 respectively.

We also found higher rates of bladder carcinoma in compare to Qatari population. The connective tissue cancer is lesser in sulaymaniyah to that of Qatar but we recorded more rates in compare to Jordan, Egypt, Cyprus, and even USA (Middle East Cancer Consortium, 2005) (table 6).

Stomach cancer in male is the eighth and in females is the ninth most common cancer in our Kurdistan region while stomach cancer accounts for the tenth cancer in Egypt and Gaza (Executive Board of the Health Ministers' Council, 2002). Stomach is common in Asia, Latin America and Eastern Europe, but lower rates found in western countries due to decreased fatty foods and an increase in vegetables. In Kurdistan may be related to the type of food and H-pylori infection. We found an AIR of 2.2 in both sexes /100,000 population/ year. Our AIR similar to Qatar, and Egypt but still we found higher 
incidence in more developed countries than our Kurdistan region.

Cervical cancer is very rare in our region $(0.45$ new cases/100,000 population/ year), while in developing countries is the leading cause of cancer related mortality (Sankaranarayanan et al., 2001). The cervical cancer can be prevented by using vaccination against the human papilloma virus (Franco and Harper, 2005).

In conclusion, finally we found that the AIR of cancers were increased in Sulaymaniyah population, we found an increased incidence of cancers with increasing age. We saw high proportion of hematological malignancies to solid malignancies. Lowest incidence of cancers reported in pediatric ages and the leukemia, lymphoma and brain cancer are common cancers in child hood age, boys more affected than girls, hematological malignancies greater than half of cases.

Common cancers in male were lung and in females were breast cancer followed by leukemia and lymphoma in both sexes, colorectal cancer is the fourth cancer in both sexes separately. Prostate in male and ovary in females were the fifth cancers in both man and women respectively. From each eight new cancer cases one were died by caner in our region per year, the mortality rate were underestimated $(5.6 / 100,1000$ population/year) because some patient died outside the hospital, the cancers associated with high mortality rate are leukemia, lung, colorectal, and breast cancers.

We declared that despite lower rates of cancer incidence in our region we still found higher annual incidence rates in some cancer in compare to the Qatar and some other countries as prostate, colorectal, brain, connective tissue, and bladder cancers. We saw similar incidence in some cancers like breast and stomach to few surrounding countries.

Lastly we think that our study is the new reliable and accurate data about the cancer incidence and mortality in Kurdistan because depended on accurate case by case selection and removal of duplicated names. We thing that the incidence still need further improvement toward a good cancer registry because till many cases had not been treated in our referral center, and they go to other country for treatment. We got difficulty in getting the exact sulaymani population that has effect on the exact incidence and age standardized incidence rates of cancers in our city.

\section{Acknowledgements}

We have special thanks to the ministry of health of Kurdistan region (Dr. Rekawt Hama-Rashid) and health directorate of Sulaymaniyah governorate (Dr. Meran Muhammad) and the professor Anwar Sheikha and Director of Hiwa hospital (Dr. Dosti N. Othman), Special thanks to Dr. Ahmed K. Yassin and Dr. Basil Kadhim the program directors of clinical hematology branch of Kurdistan board for medical specialties in Erbil and Sulaymaniyah and our thanks to pathology laboratory in Shorsh hospital and our regard to Dr. Belal A. Muhammad at university of Komar and all doctors and staffs in Hiwa hospital especially the cancer registry unit staffs (Ismail M. and Ardalan A.) Who helped us in collecting data for this publication.

\section{References}

Abdulbari B, Hanadi A, Rasul K, et al (2007). Patterns of cancer incidence among the population of Qatar:a worldwide comparative study. Asian Pac J Cancer Prev, 9, 19-24.

Ahmed AS, Omiston S, Saieni PD (2015). Trends in the lifetime risk of developing cancer in Great Britain; Comparison of risk for those born in 1930 to 1960. Br J Cancer, 606 .

Anzola M (2004). Hepatocellular carcinoma: role of hepatitis $\mathrm{B}$ and hepatitis $\mathrm{C}$ viruses proteins in hepatocarcinogenesis. $J$ Viral Hepat, 11, 383-93.

Bener A, Alwalsh R, Miller CJ, et al (2001). Knowledge, attitudes, and practices related to breast cancer screening: asurvey of Arab women. J Cancer Educ, 16, 215-20.

Boyle P (1995). Progress in preventing death from colorectal cancer [Editorial]. Br J Cancer, 72, 528-30.

Denic S, Bener A, Sabri S, et al (2005). Parental consanguinity and risk of breast cancer: a population-based case-control study. Med Sci Monit, 11, 415-9.

Boyle P, Gray N, Zatonski W et al (2003). Tobacco: Public Health Disaster of the Twentieth Century, Oxford, UK, Oxford University Press 2003.

Denny L (2005). The prevention of cervical cancer in developing countries. BJOG, 112, 1204-12.

Doll R, Peto R, Boreham J, et al (2005). Mortality from cancer in relation to smoking: 50 years observations on British doctors. Br J Cancer, 92, 426-9.

El-Helal T, Bener A, Galadari I (1997). Pattern of cancer in the United Arab Emirates. Annals of Saudi Medicine, 17, 506-9.)

Executive Board of the Health Ministers' Council, Cancer incidence report of Gulf Cooperation Council countries for the year 1998, Riyadh, Saudi Arabia, April 2002.

Facer CA, Playfair JH (1989). Malaria, Epstein-Barr virus, and the genesis of lymphomas. Adv Cancer Res, 53, 33-72.

Faivre J, Dancourt V, Lejeune C, et al (2004). Reduction in colorectal cancer mortality by fecal occult blood screening in a French controlled study. Gastroenterology, 126, 1674-80.

Ferlay J, Bray F, Pisani P, Parkin D. GLOBOCAN 2002. Cancer incidence, mortality and prevalence worldwide. IARC Cancer Base No. 5, version 2.0 2004.

Ferlay J, Autier P, Boniol M, et al (2007). Estimates of the cancer incidence and mortality in Europe in 2006. Ann Oncol, 18, 581-92.

Ferlay, J, Shin, HR., Bray, F, et.al. (2010), Estimates of worldwide burden of cancer in 2008: GLOBOCAN 2008. Int J Cancer, 127, 2893-917.

Fischbach W, Tacke W, Greiner A, et al (1997). Regression of immunoproliferative small intestinal disease after eradication of Helicobacter pylori. Lancet, 349, 31-2.

Franco EL, Harper DM (2005). Vaccination against human papillomavirus infection: a new paradigm in cervical cancer control. Vaccine, 23, 2388-94.

Jones SB (1999). Cancer in the developing world: a call to action. $B M J, 319,505-8$.

International Agency for Research on Cancer (2004). Monographs on the evaluation of carcinogenic risks to humans, vol 83. tobacco smoke and involuntary smoking. lyon, France: IARC 2004.

Kahan E, Ibrahim AS, El Najjar K, et al (1997). Cancer patterns in the middle east--special report from the middle east cancer society. Acta Oncol, 36, 631-6.

Khoshnaw N, Francis B, Safar B, et al (2014) Cytogenetic response in chronic myeloid leukaemia patients treated with imatinib mesylate homolog-drugs: 6 year's transitional study. J Cancer Therapy, 5, 453-9. 
Ma X, Yu H (2006). Global burden of cancer. Yale J Biol Med, 79, 85-94.

Magrath I, Jain V, Bhatia K (1992). Epstein-Barr virus and Burkitt's lymphoma. Semin Cancer Biol, 3, 285-95.

Magrath I, Jain V, Bhatia K, et al (1992). Epstein-barr virus and burkitt's lymphoma. Seminars in Cancer Biology, 3, 285-95.

Magrath I, Litvak J (1993). Cancer in developing countries: opportunity and challenge. J Natl Cancer Inst , 85, 862-74.

Majid R, Mohammed H, Hassan H, et al (2012). A populationbased study of Kurdish breast cancer in northern Iraq: Hormone receptor and HER2 status. A comparison with Arabic women and United States SEER data. BMC Women's Health, 12, 16

Middle East Cancer Consortium. Manual of standards for cancer registration.2005. Available at at: http://mecc.cancer.gov/ MECC_Manual_of_Standards.PDF.

Monzer B, Sepetdjian E, Saliba N, et al (2008). Charcoal emissions as a source of $\mathrm{CO}$ and carcinogenic PAH in mainstream narghile waterpipe smoke. Food Chem Toxicol, 46, 2991-5.

Othman RT, Abdulljabar R, Saeed A, et al (2011). Cancer incidence rates in the Kurdistan region/Iraq from 2007-2009. Asian Pac J Cancer Prev, 12, 1261-4.

Parkin DM, Pisani P, Ferlay J (1999). Global cancer statistics. CA: Cancer J Clin, 49, 33-64.

Plesnicar S, Plesnicar A (2001). Cancer: a reality in the emerging world. Semin Oncol, 28, 210-6.

Quinn MJ, d'Onofrio A, Moller B, et al (2003). Cancer mortality trends in the EU and acceding countries up to 2015. Ann Oncol, 14, 1148-52.

Rastogi T, Hildesheim A, Sinha R (2004). Opportunities for cancer epidemiology in developing countries. Nat Rev Cancer, 4, 909-17.

Salminen E, Izewska J, Andreo P (2005). IAEA's role in the global management of cancer-focus on upgrading radiotherapy services. Acta Oncol, 44, 816-24.

Sankaranarayanan R, Budukh AM, Rajkumar R (2001). Effective screening programmes for cervical cancer in low- and middle-income developing countries. Bull World Health Organ, 79, 954-62.

Sener SF, Grey N (2005). The global burden of cancer. J Surg Oncol, 92, 1-3.

Shin HR, Ahn YO, Bae JM, et al (2002). Cancer incidence in Korea, Cancer Res Treat, 34, 405-8

Stewart BW, Kleihues P (2003). International Agency for Research on Cancer, World cancer report, Lyon, France: IARC Press 2003.

Siegel R, Ma J, Zou Z, et.al (2014), Cancer statistics, 2014. CA: A Cancer J Clin, 64, 9-29.

World Health Organization, (2003), Global cancer rates could increase by $50 \%$ to 15 million by 2020 , sciencedaily, 4 April 2003.

www.sciencedaily.com/releases/2003/04/030404073045.htm

www.werf-Ukorg/report/preliminary (2007), J Natl Cancer Inst, 95, 1258-61

www.cia.gov/library/publications/the-world-factbook/geos/ iz.html

Zangana A, Garota S (2012). Risk factors of breast cancer in a sample of Kurdish women of Kurdistan Region - Iraq: a comparative study between pre-menopausal and postmenopausal women, Zanco. J Med Sci, 16, 3. 